\title{
APPLICABILITY OF SHOPE FIBROMA VIRUS REPLICATED IN CELL CULTURES FOR IMMUNOPROPHYLAXIS OF RABBIT MYXOMATOSIS
}

\author{
J. JER̆ÁBEK \\ Department of Prophylaxis of Pig Diseases, Animal Breeding \\ and Zoohygiene, University of Veterinary Science, 61242 Brno
}

Received April 13, 1979

\begin{abstract}
Jeřábek J.: Applicability of Shope Fibroma Virus Replicated in Cell Cultures for Immunoprophylaxis of Rabbit Myxomatosis. Acta vet. Brno, 49, 1980: 259-267.

Shope fibroma virus replicated on cell cultures of RK 13 line is suitable for the preparation of lyophylized vaccine against myxomatosis in rabbits. The vaccine is safe and its efficiency is satisfactory. After a single subcutaneous application good immunity may be expected for next three months. Revaccination provides further extension of immunity with $75 \%$ of vaccinated population still immune seven months later.
\end{abstract}

Myxomatosis, vaccination, Shope fibroma virus, in vitro cultivation.

In principle, two types of vaccines have been employed for the immunoprophylaxis of myxomatosis in rabbits: 1. Vaccines prepared from Shope fibroma virus (SFV) have been used since the discovery of rabbit immunity against myxomatosis after the application of this virus (Shope 1932; Shope 1936a; Shope 1936b; Shope 1938; Rowe, Mansi and Hudson 1956; Jacotot, Vallée and Virat 1958; Roemmele 1958; Durand et al. 1974; Matthes 1978). 2. Vaccines prepared from the attenuated myxomatosis virus (Anonymous 1970; Jiran, Sladká and Kunstýr 1970; Saurat, Gilbert, Ganière 1978).

It follows from the literature to date that none of the vaccine types reported can ensure permanent immunity after a single or revaccination followed vaccination (Eissner 1966; Durand et al. 1974; Loquerie, Rayon, Durand 1977; Saurat, Gilbert, Ganière 1978; Eissner, Weber 1978). To achieve satisfactory immunity against myxomatosis it is thus advantageous to work out a suitable vaccination scheme rather than choosing one or another type of vaccine. When attenuated myxomatosis virus is applied the question remains to be solved concerning possible circulation of the vaccination virus in rabbit population (Anonymous 1973).

So far, Shope fibroma virus (SFV) for the vaccine preparation has been replicated in rabbits (Mádr, Macura, Petlach 1967; Mádr 1971; Jacquemont et al. 1972; Anonym 1973).

Although there are reports on SFV replication facilitated in different cells in vitro (Kilh a m 1957; Kilham 1959; Verna, Eylar 1962; Hinze, Walker 1964; Israeli, Sachs 1964; Woodroofe, Fenner 1965; Hinze, Walker 1971; Tektoff, Gazzolo, Leftheriotis 1971; Jacquemont et al. 1972) the possibility of use of such virus for the vaccination purposes has not yet been considered. This report describes the results concerning vaccine preparation from in vitro replicated SFV.

\section{Materials and Methods}

\section{Cell cultures}

Taking into account that SFV may be successfully cultured in cells of rabbit origin (Jacque mont et al. 1972) we employed the RK 13 cell line of rabbit kidney. Two types of growth media have been tested: Earle medium and MEM (Eagle) medium. Both media were supplemented by $10 \%$ of fetal bovine serum for cell cultures. Because the Earle medium proved to be suitable 
only up to the fourth passaging of RK 13 cell line exclusively the MEM medium was used for further replications. Using the latter medium it was possible to obtain the cell monolayers suitable both for virus passaging and for the actual vaccine preparation. As the medium for culture maintenance after the infection of cell monolayer the Earle as well as MEM media were used, none of them containing bovine serum.

\section{Culture passaging of $\mathrm{RK} 13$ cell line}

The subpassages of RK 13 cell line were prepared from well developed cultures preserved in Roux bottles, usualy after a week's intervals. After the removal of medium the culture was washed with the versen-trypsin solution at $37^{\circ} \mathrm{C}$, then rinsed and immersed for 5 minutes into versen-trypsin. After this time the supernatant was removed and the bottles were turned so that their culture containing parts were facing up. In this arrangement they were placed into a thermostat at $37^{\circ} \mathrm{C}$ for 20 minutes. When the residual versen-trypsin was decanted the free cells were mixed to form a suspension in the MEM growth medium. Out of one Roux bottle contents usually 3 vessels of the same culture volume were obtained.

\section{Virus}

The starting strain for the adaptation to the RK 13 cell line the commercial vaccine against rabbit myxomatosis was selected. This vaccine is prepared from SFV replicated on rabbits and it has been commercially produced by Bioveta at Ivanovice na Hané.

\section{Challenge virus}

To check the immunity after the SFV application the dose corresponding to $1000 \mathrm{ID}_{50}$ of virulent myxomatosis virus was applied upon carrying out the preliminary experiments (Jeřábek unpublished results) which revealed no difference in the course of myxomatosis after the challenge by $10^{2}-10^{5} \mathrm{ID}_{50}$ of virulent myxomatosis virus in rabbits. The overall challenge dose $\left(1000 \mathrm{ID}_{50}\right)$ was administered into both conjunctival sacs (one drop each), the rest (up to $1 \mathrm{ml}$ ) being applied subcutaneously.

\section{Rabbits}

To make sure that both vaccine and the virus passaged on RK 13 cell line are safe and efficient, healthy animals weighing $1.5-2.0 \mathrm{~kg}$ were selected out of breeds where no previous vaccination against myxomatosis was carried out.

\section{Procedure of virus passaging}

Three-day-old cell monolayers of RK 13 cell line were used for the infection by virus. These monolayers were prepared in two ways:

1. The same procedure as that applied for passaging cultures of the RK 13 cell line

2. The same as above, the only difference being the use of Earle medium.

This second possibility may be employed only for the preparation of culture which is to be used for the infection by virus. As already mentioned the Earle medium cannot be used for a routine passaging of RK 13 cell line cultures.

\section{Virus passaging}

The developed monolayer of RK 13 cells was infected by the storage virus (i. e. the suspension of virus from the previous passage) and after a 30 minutes' adsorption the contents of Roux bottle were filled with the nine-fold amount of medium $\left(3 \mathrm{~cm}^{3}\right.$ of virus and $27 \mathrm{~cm}^{3}$ of medium were applied in the case of $300 \mathrm{~cm}^{3}$ bottles, $5 \mathrm{~cm}^{3}$ of virus and $45 \mathrm{~cm}^{3}$ of medium for $500 \mathrm{~cm}^{3}$ bottles and $10 \mathrm{~cm}^{3}$ of virus and $90 \mathrm{~cm}^{3}$ of medium for $1000 \mathrm{~cm}^{3}$ bottles). In case that the RK 13 line cells were cultivated prior to infection in the MEM growth medium, the maintenance MEM medium was added. When the Earle medium was used for replication of cells to be infected, the medium for maintenance according to Earle was also used. The adaptation of virus as well as its other passage on the RK 13 cell line was thus carried out parallely in MEM and Earle medium.

After filling up the medium the cultivation of the virus proceeded in a stationary manner at $37^{\circ} \mathrm{C}$. When a significant cytopathic effect occurred (4th post - infection day) on the infected cells the latter were subjected to three freeze and thaw cycles. The suspensions obtained in this way represented the virus which was used for further passage. Efficiency and safety were verified in rabbits with the tenth and twentieth passage.

\section{The vaccine preparation}

The virus obtained from the tenth passage of RK 13 cell line was used for the actual vaccine preparation. Procedures of monolayer preparation and infection were identical with that of virus passage. After three freeze - thaw cycles the contents of individual Roux bottles were joined and the 
suspension thus obtained was stored at $-20^{\circ} \mathrm{C}$. Upon thawing, the suspension was mixed with the liquid lyophilic medium $(0.5 \mathrm{ml}$ of medium per $1 \mathrm{ml}$ of suspension). The composition of medium was following: gelatine for bacteriology $300 \mathrm{~g}$; sucrase $450 \mathrm{~g} ; \mathrm{Na}_{2} \mathrm{HPO}_{4} \cdot 12 \mathrm{H}_{2} \mathrm{O} 22.92 \mathrm{~g}$; $\mathrm{KH}_{2} \mathrm{PO}_{4} 2.92 \mathrm{~g}$; redistilled water $6000 \mathrm{~cm}^{3}$. After the lyophilization and the sterility control tests were carried out establishing vaccine efficiency and safety. Invariably $6 \mathrm{~cm}^{3}$ were taken for lyophilization; these contained $4 \mathrm{~cm}^{3}$ of virus suspension and $2 \mathrm{~cm}^{3}$ of lyophilic medium. Twenty vaccination doses were obtained upon dilution of the lyophilizate with $20 \mathrm{~cm}^{3}$ of diluent. The latter was either MEM and Earle medium, or buffered saline.

The efficiency and safety of vaccine were tested according to procedure adopted in Czechoslovakia for rabbit myxomatosis vaccine prepared from SFV replicated in rabbits.

After the control tests had been completed the production of the lyophilized vaccine has started up under the commercial name SFT rabbit myxomatosis vaccine (SFT standing for Shope Fibroma virus replicated in Tissue cultures).

Safety test

Four experimental rabbits were observed for health status upon application of vaccine.

\section{Procedure}

Rabbits with shaved backs were employed. Each animal was given $3 \mathrm{~cm}^{3}$ of commercial vaccine intradermally by 12 injections à $0.25 \mathrm{~cm}^{3}$. Another two animals were given subcutaneous dose ( $3 \mathrm{~cm}^{3}$ each) applied on two separate sites (behind shoulder blade).

\section{Evaluation of the test}

The experimental animals are observed for 21 days. In intradermally inoculated animals pea-or bean-sized fibroma must develop at the site of application of vaccine but no generalization of fibromatosis may occur. Subcutaneously vaccinated animals must not exhibit general fibromatosis or more serious local changes.

A small local fibroma occurring at the site of application is not considered serious. It is usually absorbed without detrimental effects before the end of observation period.

Apart from the above - mentioned test the safety of vaccine was checked by the subcutaneous application of vaccine to young animals after weaning.

During the safety and efficiency testing of SFT vaccine in rabbits also the pure culture RK 13, containing no SFV, was inoculated intradermally (similarly to procedure applied for the virus titration). Two rabbits were given the suspension in MEM while in the other two cases the Earle medium was used. No reaction was observed upon the intradermal application. Upon challenge the animals developed myxomatosis and died.

The test of vaccine efficiency

and of the passaged virus was made by determining $\mathrm{ID}_{50}$ according to Reed and Muench (1938) after the titration on rabbits. Moreover, challenge followed upon the application of passaged virus and one vaccination dose, respectively. The titres of virus in individual passages and in the prepared vaccine were compared with that of virus (vaccine) replicated in classical way in rabbit skin.

\section{Virus titration}

The titrations of harvested virus and lyophilized vaccine were always carried out by intradermal testing on the shaved backs of two experimental animals. Each rabbit was given $0.25 \mathrm{~cm}^{3}$ of the undiluted vaccine or virus suspension. Moreover, corresponding dilutions down to $10^{-5}$ were administered. Each dilution was applied by eight injections at the rate of $0.25 \mathrm{~cm}^{3}$. The reaction was evaluated from 6 th to 12 th day after the application. The size of developed fibromas was measured. The skin thickness was subtracted from the observed value in $\mathrm{mm}$. The increase in thickness of $1 \mathrm{~mm}$ and more was considered positive for the calculation of $\mathrm{ID}_{50}$.

Comparing $\mathrm{ID}_{50}$ of individual virus passages or vaccines it was possible, according to titres, to evaluate their efficiency but the experimental values did not quite reflect the intensity of reaction of individual tests. Therefore a complementary criterion was adopted and referred to as overall reaction number (ORN) which represents an average of all daily sums (from 6th to 12th day) of all thickness increases in $\mathrm{mm}$ (size of fibromas) upon the application of individual dilutions of the virus being studied. The comparison of ORN corresponding to individual passages or vaccines contributes to a better comparison of their effectiveness.

The determination of protective doses in one vaccination dose $\left(\mathrm{PD}_{50}\right)$

Although the comparison of $\mathrm{ID}_{50}$ and $\mathrm{ORN}$ of individual passages of virus or vaccines enables to compare their relative effectiveness, the immunogenic effect of the vaccination dose is not sufficiently expressed i. e. it is not known how many protective doses are present in one vaccination 


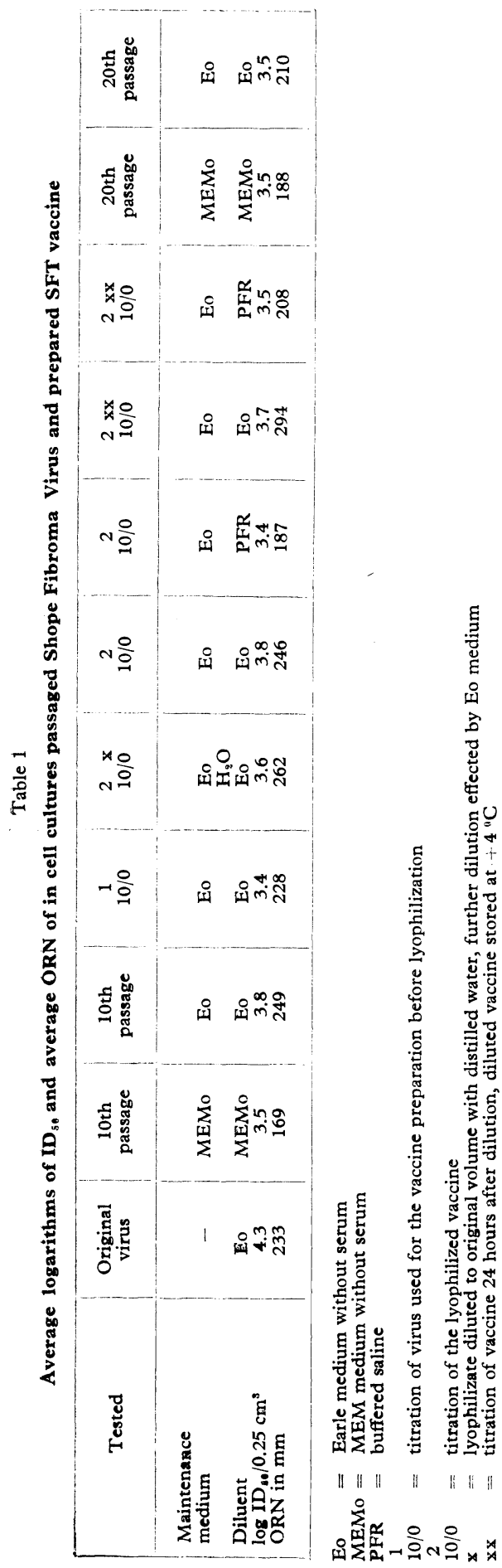

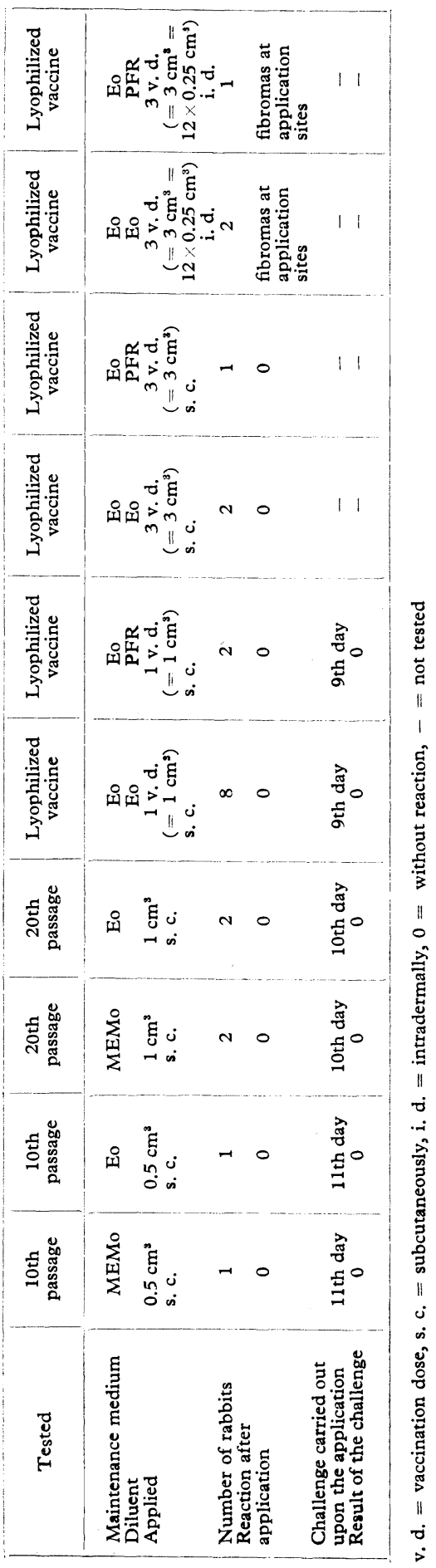


dose. Therefore the number of protective doses $\left(\mathrm{PD}_{50}\right)$ was determined by means of titration on rabbits. To determine their value the calculation by Reed and Muench (1938) was employed.

The lyophilized virus suspension was diluted to the original volume $\left(=10^{\circ}\right)$ with redistilled water used for the preparation of tissue culture media. Further dilution was effected using the Earle medium for culture maintenance. The groups of experimental animals were given the individual dilutions of vaccine, the dose being $1 \mathrm{~cm}^{3}$ each. After 19 days of application the rabbits were infected with $1000 \mathrm{ID}_{50}$ of virulent myxomatosis virus. After the challenge the rabbits were observed for 6 weeks. Two standpoints were considered for the determination of $\mathrm{PD}_{30}: 1$. Only those animals were considered to be surviving for the determination of $\mathrm{PD}_{50}$ which exhibited no reaction upon the challenge; 2 . As surviving animals also those were considered which developed a reaction at the site of inoculation (primary myxoma) or temporary myxomatosis (benign myxomatosis).

The test of effectiveness by challenges of vaccinated rabbits at various time intervals after a single vaccination and after vaccination followed by revaccination

The vaccination dose of $1 \mathrm{~cm}^{3}$ was always used for both the vaccination and revaccination of rabbits. The revaccination was done 25 th day after the first vaccination. The challenge was effected at various times after vaccination (revaccination) using the usual dose of myxomatous virus; the rabbits were then observed for 21 days.

In all tests of effectiveness of passaged SFV and of the vaccine prepared from it always two control rabbits were infected by the same challerige dose which upon challenge developed myxomatosis and died or were killed.

\section{Results}

\section{Titration of passaged virus and of prepared vaccine}

Table 1 indicates that when compared with the original virus titre the titres were lower by $0.5-0.9$ logs and that the ORN is not always directly dependent on $\log \mathrm{ID}_{50}$. It is further obvious that the maintenance medium Eo is suitable for virus replication as well as a diluent of lyophilized vaccine. This fact is important from the economical point of view as well. Also buffered saline can be used for dilutions. The decrease of diluted vaccine effectiveness did not occur during 24 hours if both maintenance medium Eo and buffered saline were used. It is also evident from the Table that during passaging neither $\log \mathrm{ID}_{50}$ decrease nor ORN decrease occurred. Moreover, none of the followed values was negatively influenced by the lyophilization.

\section{Assay of safety and of effectiveness of passaged virus and pre- pared vaccine}

Upon the subcutaneous application of various doses of passaged virus and prepared vaccine no postvaccination reaction was observed (Table 2). Upon intradermal inoculation only fibromas at the inoculation site occurred. All rabbits, which had been challenged by virulent myxomatous virus, on the 9th-11th day after the subcutaneous application of passaged virus or vaccine, survived without reaction. Although no groups of the same number of experimental rabbits were used it is evident from Table 2 that no difference was found when two different diluents were used, i. e. Earle maintenance medium and buffered saline.

Apart from the results presented in Table 2 the safety and effectiveness of prepared vaccine were tested on young animals from two not vaccinated females.

From one mother three young rabbits were vaccinated immediately after weaning at the age of 23 days by the dose of $1 \mathrm{~cm}^{3}$ of diluted lyophilized vaccine (determined vaccination dose). No postvaccination reaction was observed. On the 45 th day after vaccination the rabbits were infected by $1000 \mathrm{ID}_{50}$ of virulent 
myxomatous virus. Apart from a slight temporary infiltration at the inoculation site in two rabbits no further symptoms of the disease were noted.

From the other female rabbit two youngs aged 29 days (also immediately after weaning) were each vaccinated by a $3 \mathrm{~cm}^{3}$ dose of diluted lyophilized vaccine, this dose being triple of that used in the previous experiment. No reaction after the vaccination was observed. Challenge carried out 34th day after the vaccination did not induce any reaction except a slight temporary infiltration at the inoculation site in one rabbit.

Number of protection doses $\left(\mathrm{PD}_{50}\right)$ in $1 \mathrm{~cm}^{3}$ of $S F T$ vaccine

To determine $\mathrm{PD}_{50}$ the SFT vaccine containing $10^{3.9} \mathrm{ID}_{50} / 0.25 \mathrm{~cm}^{3}$ of lyophilized virus suspension, as found by titration on rabbits (see Table 1) was used.

Data to be used for the $\mathrm{PD}_{5}$, calculation are presented in Table 3 . Since the commercial SFT vaccine consists of lyophilizate (equal to $4 \mathrm{~cm}^{3}$ of virus suspension and $2 \mathrm{~cm}^{3}$ of lyophilic medium) which is diluted by $20 \mathrm{~cm}^{3}$ of diluent prior to vaccination, $1 \mathrm{~cm}^{3}$ of diluted vaccine, that is one vaccination dose, contains $12.6-400 \mathrm{PD}_{50}(4 \times 63.1=252.4: 20=12.6 ; 4 \times 2000=8000: 20=400)$.

Table 3

Determination of $\mathrm{PD}_{50}$ in $1 \mathrm{~cm}^{3}$ of SFT vaccine

\begin{tabular}{|c|c|c|c|c|c|}
\hline Dilution & Number of rabbits & \multicolumn{2}{|c|}{$\begin{array}{l}\text { a) Reaction to challenge } \\
\text { negative }\end{array}$} & \multicolumn{2}{|c|}{$\begin{array}{l}\text { b) Reaction to challenge } \\
\text { negative positive }\end{array}$} \\
\hline $\begin{array}{l}10^{-6} \\
10^{-5} \\
10^{-4} \\
10^{-2} \\
10^{-2} \\
10^{-1} \\
10^{0}\end{array}$ & $\begin{array}{l}4 \\
4 \\
4 \\
3^{*} \\
4 \\
3^{*} \\
4\end{array}$ & $\begin{array}{l}0 \\
1 \\
1 \\
1 \\
1 \\
1 \\
1 \\
4\end{array}$ & $\begin{array}{l}4 \\
3 \\
3 \\
2 \\
3 \\
2 \\
0\end{array}$ & $\begin{array}{l}0 \\
1 \\
3 \\
2 \\
2 \\
1 \\
4\end{array}$ & $\begin{array}{l}4 \\
3 \\
1 \\
1 \\
2 \\
2 \\
0\end{array}$ \\
\hline \multicolumn{2}{|l|}{$\mathrm{PD}_{50}$} & \multicolumn{2}{|c|}{$=10^{-1.8} / 1 \mathrm{~cm}^{3}$} & \multicolumn{2}{|c|}{$=10^{-3.3} / 1 \mathrm{~cm}^{3}$} \\
\hline \multicolumn{2}{|c|}{$\begin{array}{l}\mathrm{PD}_{50} \text { contained in one vaccination } \\
\text { dose }\end{array}$} & & & 40 & \\
\hline
\end{tabular}

a) Only those rabbits were used for the determination of $\mathrm{PD}_{50}$ which did not exhibit any reaction after the challenge

b) To determine $\mathrm{PD}_{50}$ rabbits exhibiting no reaction and those with the benign myxomatosis upon challenge have been used

* The fourth rabbit from the experimental group diel for other reason

The immunity duration in rabbits with single vaccination and in rabbits vaccinated and revaccinated by the same SFT vaccine dose on the 25 th day after the first vaccination

The result of immunity duration studies after a single vaccination are given in Table 4. Up to the 84th day after a single vaccination the rabbits did not react upon challenge by virulent myxomatosis virus. In rabbits infected within a longer time interval after the vaccination the reaction induced by challenge was more distinct and apart from myxomatosis with benign course a typical myxomatosis with subsequent death developed.

The results of immunity duration studies after vaccination followed by subsequent revaccination are summarized in Table 5 . It is evident that up to the 121st 
Table 4

The immunity of rabbits vaccinated subcutaneously using $1 \mathrm{~cm}^{3}$ of SFT

\begin{tabular}{|c|c|c|c|c|c|}
\hline \multirow{2}{*}{$\begin{array}{c}\begin{array}{c}\text { Number of rabbits } \\
\text { followed }\end{array} \\
\\
4 \\
3 \\
4 \\
4 \\
4 \\
4 \\
3\end{array}$} & \multirow{2}{*}{ 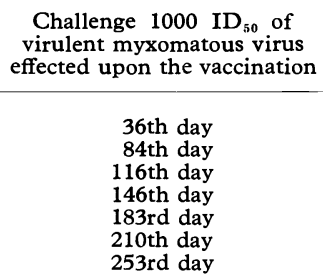 } & \multicolumn{4}{|c|}{ Result of challenge } \\
\hline & & $\begin{array}{l}\text { BN } \\
\text { BN } \\
\text { BN. } \\
\text { BN } \\
\text { BN } \\
\text { BN } \\
\text { BN- }\end{array}$ & $\begin{array}{l}\text { BN } \\
\text { BN } \\
\text { BN. } \\
\text { BM } \\
\text { BN - } \\
\text { BN- } \\
\text { BM }\end{array}$ & $\begin{array}{l}\text { BN } \\
B N \\
B M \\
B M \\
B M \\
M \\
M\end{array}$ & $\begin{array}{l}\text { BN } \\
\text { BM } \\
\text { BM } \\
\text { M } \\
M\end{array}$ \\
\hline
\end{tabular}

BN no myxomatosis symptoms

BN. no effect, only local temporary reaction at the inoculation site of myxomatous virus

BN- only temporary increased breathing and congestion of conjuctiva

BM myxomatosis reaction followed by a subsequent recovery recovery (benign course of myxomatosis)

M myxomatosis with a typical course, animal died or was killed

Table 5

Immunity of rabbits subcutaneously vaccinated and revaccinated with $1 \mathrm{~cm}^{3}$ of SFT vaccine 25 th day after the first vaccination

\begin{tabular}{|c|c|c|c|c|c|}
\hline $\begin{array}{l}\text { Number of animals } \\
\text { followed }\end{array}$ & $\begin{array}{l}\text { Challenge } 1000 \mathrm{ID}_{50} \text { of the } \\
\text { virulent myxomatous virus }\end{array}$ & \multicolumn{4}{|c|}{ Result of challenge } \\
\hline $\begin{array}{l}4 \\
2 \\
4 \\
4 \\
4 \\
4\end{array}$ & $\begin{array}{l}\text { 59th day } \\
102 \text { nd day } \\
121 \text { st day } \\
158 \text { th day } \\
185 \text { th day } \\
228 \text { th day }\end{array}$ & $\begin{array}{l}\text { BN } \\
\text { BN } \\
\text { BN } \\
\text { BN } \\
\text { BN } \\
\text { BN }\end{array}$ & $\begin{array}{l}\text { BN } \\
\text { BN. } \\
\text { BN } \\
\text { BK } \\
\text { BN } \\
\text { BN }\end{array}$ & $\begin{array}{l}\mathrm{BN} \\
\mathrm{BN} \\
\mathrm{BN} . \\
\mathrm{BN} \\
\mathrm{BN}-\end{array}$ & $\begin{array}{l}\mathrm{BN}- \\
\mathrm{BN}- \\
\mathrm{M} \\
\mathrm{M} \\
\mathrm{BN}-\end{array}$ \\
\hline
\end{tabular}

day after revaccination all rabbits survived the challenge without a marked reaction. The challenges effected from 158th to 228th day (no experiments with longer period have been conducted) after the revaccination $75-100 \%$ of rabbits survived without more distinct reaction.

Comparison of data presented in Table 4 and 5 shows that better immunity is obtained in rabbits vaccinated and revaccinated.

\section{Discussion}

It follows from hitherto available data on immunoprophylaxis of myxomatosis that no vaccine exists guaranteing a long-lasting immunity after single vaccination or after vaccination followed by revaccination in a vaccinated rabbit population. This fact is important mainly for breeding animals where vaccination scheme providing a satisfactory immunity has to be chosen for a period of myxomatosis peak occurrence.

Present results show that the SFT vaccine prepared from SFV replicated on monolayer of RK 13 cell line yields at least the same effect as vaccines against rabbit myxomatosis at present produced abroad.

The replication of virus in a defined standard cell substrate and in a maintenance medium guarantees the preparation of safe and effective vaccine. The use of Earle maintenance medium for virus multiplication and of the same medium or buffered saline as a diluent of lyophilized vaccine is advantageous also from the economical point of view. 
By orientation testing on young animals and by experiments on mature rabbits it has been established (Matthes 1978) that the vaccine prepared from the SFV is safe for rabbits of various age categories. The subcutaneous vaccination is not followed by postvaccination reactions. This fact confirms the data by Eissner (1966) who found that the immunity was not dependent on the fibroma development at the site of inoculation. In one vaccination dose (equal to $1 \mathrm{ccm}$ ) $12.6-$ $-400 \mathrm{PD}_{50}$ is contained.

When vaccination with subsequent revaccination were employed practically $100 \%$ immunity was found four months after the revaccination. Even seven months after revaccination (experiments with longer time period have not been undertaken) the immunity was found to be solid in at least $75 \%$ of vaccinated population. If a single vaccination was effected the same degree of immunity could be expected approximately for three months. It follows from the above stated data that by vaccination with subsequent revaccination using SFT vaccine in spring months a solid immunity in rabbits could be ensured for the rest of the year.

\section{Použitelnost viru Shopeho fibromu pomnožovaného na buněčných kulturách $\mathrm{k}$ imunoprofylaxi myxomatózy králíků}

Virus Shopeho fibromu pomnožovaný na buněčných kulturách linie RK 13 je vhodný $k$ prípravě lyofilizované vakcíny proti myxomatóze králíkủ, která je neškodná a dostatečně účinná. Po jednorázové podkožní aplikaci vakcíny je možno počítat se solidní imunitou po dobu tří měsícủ. Po vakcinaci s následnou revakcinací je možno ještě za sedm měsíců počítat se solidní imunitou nejméně u $75 \%$ vakcinované populace.

\section{Применяемость вируса Фибромы Шоупа, разможенного на клеточных культурах, для иммунопрофилактики миксоматоза проликов}

Вирус фибромы Шоупа, размноженный на клеточных культурах линии РК 13 удобен для подготовки лиофилизированной вакцины против миксоматоза кроликов, которая безвредна и достаточно действенна. После однократного подкожного ввода вакцины можно положиться на возникновение устойчивого иммунитета в течение трех месяцев. После вакцинации с послешующей повторной вакцинацией можно еще спустя семь месяцев положиться на устойчивый иммунитет минимально в $75 \%$ вакцинированных кроликов.

Acknowledgement

The author thanks Ing. L. Šimková for technical assistance.

\section{References}

ANONYMOUS: Anti-myxomatosis vaccine. Pat. Francie 2088 089, 1970.

ANONYMOUS: Vaccin contre la myxomatose des lapins. Pat. Francie 2229 397, 1973.

DURAND, M. - RAVON, D. - GUERCHE, J. - PRUNET, P.: Étude d'un nouveau vaccin contre la myxomatose. Rec. Méd. Vét., 150, 1974: 527.

EISSNER, G.: Zur Schutzimpfung gegen Kaninchenmyxomatose. Zentbl. Bakt. ParasitKde, Abt. 1, Referate, 201, 1966: 327. 
EISSNER, G. - WEBER, R.: Erfahrungen mit der Myxomatoseschutzimpfung. Prakt. Tierarzt, 59, 1978: 9.

HINZE, H. C. - WALKER, D. L.: Response of cultured rabbit cells to infection with the Shope fibroma virus. I. Proliferation and morphological alternation of the infected cells. J. Bact., 88, 1964: 1185.

HINZE, H. C. - WALKER, D. L.: Comparison of cytocidal and noncytocidal strains of Shope rabbit fibroma virus. J. Virol., 7, 1971: 577.

ISRAELI, E. - SACHS, L.: Cell-virus interactions with Shope fibroma virus on cultures of rabbit and rat cells. Virology, 23, 1964: 473.

JACOTOT, H. - VALLÉE, A. - VIRAT, B.: Sur l'immunisation contre le virus du myxome infectieux par inoculation de virus du fibroma de Shope. Annals Inst. Pasteur, 94, 1958: 282.

JACQUEMONT, B. - OGIER, G. - LEFTHERIOTIS, E. - CHARDONNET, Y.: Étude de quelques propriétés biologiques du virus du fibrome de Shope: titrage et production du virus ,,in vivo" et ,in vitro“. Annls Inst. Pasteur, 122, 1972: 489.

JIRAN, E. - SLADKÁ, M. - KUNSTÝR, I.: Myxomatose der Kaninchen - Beitrag zur Virus-Modifizierung. Zentbl. Vet. Med., B 17, 1970: 418.

KILHAM, L.: Transformation of fibroma into myxoma virus in tissue culture. Proc. Soc. exp. Biol. Med., 95, 1957: 59.

KILHAM, L.: Relation of thermoresistance to virulence among fibroma and myxoma viruses. Virology, 9, 1959: 486.

LOQUERIE, R. - RAVON, D. - DURAND, M.: Étude d'un nouveau vaccin contre la myxomatose. Revue Méd. vét., 128, 1977: 1083.

MÁDR, V. - MACURA, B. - PETLACH, J.: Vakcína proti myxomatóze králíkủ z viru infekčního fibromu. Imunoprofylaxia, Bratislava, 1967: 90.

MÁDR, V.: Vývoj vakcíny proti myxomatóze králíkủ. (Závěrečná zpráva.) Ivanovice na Hané, Bioveta, 1971.

MATTHES, S.: Untersuchungen zur Verträglichkeit der Myxomatoseschutzimpfung bei trächtigen, laktierenden und wachsenden Kaninchen. Prakt. Tierarzt, 59, 1978: 12.

REED, L. J. - MUENCH, H.: A simple metod of estimating fifty per cent endpoints. Am. J. Hyg., 27, 1938: 493.

ROEMMELE, O.: Erfolgreiche Schutzimpfung mit Shopescher Vaccine gegen Myxomatose der Hauskaninchen und Infektivitätsversuche. Berl. Münch. tierärztl. Wschr., 71, 1958: 128.

ROWE, B. - MANSI, W. - HUDSON, J. R.: The use of fibroma virus (Shope) for the protection of rabbits against myxomatosis. J. comp. Path., 66, 1956: 290.

SAURAT, P. - GILBERT, Y. - GANIËRE, J. P.: Étude d'une souche de virus myxomateux modifié. Revue Méd. vét., 129, 1978: 415.

SHOPE, R. E.: A filterable virus causing a tumor-like condition in rabbits and its relationship to virus myxomatosum. J. exp. Med., 56, 1932: 803.

SHOPE, R. E.: Infectious fibroma of rabbits. III. The serial transmission of virus myxomatosum in cottontail rabbits and cross immunity tests with the fibroma virus. J. exp. Med., 63, 1963a: 33.

SHOPE, R. E.: Infectious fibroma of rabbits. IV. The infection with virus myxomatosum of rabbits recovered from fibroma. J. exp. Med., 63, 1936b: 43.

SHOPE, R. E.: Protection of rabbits against naturally acquired infectious myxomatosis by previous infection with fibroma virus. Proc. Soc. exp. Biol. Med., 38, 1938: 86.

TEKTOFF, J. - GAZZOLO, L. - LEFTHERIOTIS, E.: Morphogénèse du virus de la myxomatose du lapin. Pathol. Biol., 19, 1971: 1045.

VERNA, J. E. - EYLAR, O. R.: Rabbit fibroma virus plaque assay and in vitro studies. Virology, 18, $1962: 266$.

WOODROOFE, G. M. - FENNER, F.: Viruses of the myxoma-fibroma subgroup of the poxviruses. 1. Plaque production in cultured cells, plaque-reduction tests, and cross-protection tests in rabbits. Austr. J. exp. Biol. med. Sci., 43, 1965: 123. 